\title{
Bilinguals are less susceptible to the bias blind spot in their second language
}

\author{
Paweł Niszczota ${ }^{1, *}$, Magdalena Pawlak ${ }^{1}$, Michał Białek ${ }^{2}$
}

\section{Accepted for publication in International Journal of Bilingualism}

${ }^{1}$ Poznań University of Economics and Business, Humans and Artificial Intelligence Laboratory (HAI Lab), Institute of International Business and Economics, Poznań, Poland

${ }^{2}$ University of Wrocław, Institute of Psychology, Wrocław, Poland

* Corresponding author: Paweł Niszczota, Poznań University of Economics and Business, al. Niepodległości 10, 61-875, Poznań, Poland; pawel.niszczota@ue.poznan.pl;

ORCID: 0000-0002-4150-3646

\section{Open Science Practices}

The experiments in this study have been pre-registered. The pre-registration documents, data, and materials are available at: https://osf.io/j43df/

\section{Funding}

The current research was supported by grant 2017/26/D/HS6/01159 from the National Science Centre (NCN, Poland), awarded to Michał Białek. The funders had no role in study design, data collection and analysis, decision to publish, or preparation of the manuscript.

\begin{abstract}
Extant research suggests that processing information in a second language (L2) affects decisionmaking, possibly by affecting metacognition. We hypothesized that processing in L2 will reduce the bias blind spot effect, whereby people (on average) erroneously think that they are less susceptible to biases than others. In Experiment 1, participants assessed their susceptibility and the susceptibility of others to 13 psychological and 7 economic biases, in either L1 (Polish) or L2 (English). In Experiment 2, participants assessed the 7 most severe bias blind spots from Experiment 1. We recruited 500 participants for each experiment via Prolific (832 overall, after exclusions). The main hypothesis and moderators were tested via mixed-model regressions. In Experiment 1, participants showed an overall bias blind spot, which decreased in the L2 condition, but only for psychological biases. In Experiment 2, we replicated the L2-bias blind spot attenuation effect. An exploratory analysis suggests that the effect of L2 is the result of both lower ratings of other-susceptibility and higher ratings of self-susceptibility. Our study provides unique insights into how L2 affects metacognition. We are the first to study how the use of L2 can attenuate the bias blind spot. Our findings provide rare support for the psychological distancing ('birds-eye view') explanation for the foreign language effect. Bilinguals using L2 showed some resilience to the bias blind spot, suggesting metacognition is language-dependent.
\end{abstract}

Keywords: bilingualism, bias blind spot, cognitive biases, economic biases, foreign language effect, judgment, metacognition 


\section{Introduction}

\subsection{Bias blind spot}

Recall the last time you were driving on a highway. People that you were passing on the outside lane are driving so slowly, that you consider it dangerous. But behind you, there is a car that is moving much faster than you: a potential road killer! It seems that everyone driving at a different speed than you is irrational: either driving too quickly or too slowly. Sounds familiar? If it does, you just recalled a phenomenon labeled as the bias blind spot (Pronin et al., 2002). The bias blind spot describes cases where people believe they are less susceptible to biases than others. That is, an average person thinks they are less biased than an average person, a belief that is clearly incorrect. A caveat of the bias blind spot is that people overestimate their accuracy mostly for easy tasks, but also tend to underestimate their decision-making abilities in difficult tasks (Scopelliti et al., 2015). This bias has far-reaching consequences for everyday decisionmaking - for example, we tend to overestimate the accuracy of our beliefs and neglect the opinions of others. The bias blind spot is likely one of the mechanisms responsible for the better-than-average effect, considered to be "the mother of all biases" (Moore \& Healy, 2008).

The source of the bias blind spot is speculated to lie either in faulty introspection (Pronin \& Kugler, 2007) or naïve realism (Ross \& Ward, 1995). Both are attributed to metacognitive processes, that is thinking about our thinking. Metacognition is unreliable because people cannot introspect on the biases that affected their thinking. Thus, people are often unable to identify the bias that affected their cognition. Additionally, people think their perception of the world reflects reality, and thus find their inflated self-assessments to be true. Because metacognition is the key factor in producing a bias blind spot and overconfidence, human cognition would greatly benefit from a more accurate evaluation of one's own versus others' cognitive processes.

In this paper, we propose a novel method to mitigate the bias blind spot: using a foreign (second) language. The foreign language effect - explained in greater detail below - suggests that cognition and metacognition are both language-dependent, with the language that is being used affecting the way information is processed. Switching to another language can therefore change how we think and decide (Hayakawa et al., 2016).

\subsection{The foreign language effect}

Using a foreign (i.e., a second (L2) or further) language has been shown to affect judgment and decision-making (Circi et al., 2021; Hadjichristidis et al., 2019; Hayakawa et al., 2016). Earlier research highlighted the benefits of using L2 on judgments and decisions, such as an attenuation of framing effects, loss aversion or reliance on superstitions (Hadjichristidis et al., 2017; Huang \& Rau, 2020; Keysar et al., 2012), and an increased proclivity to take gambles with a positive expected value (Hadjichristidis et al., 2015). Later studies showed that effects are not solely beneficial, as using a foreign language can also deteriorate thinking, e.g., increase impulsivity (Białek et al., 2022), decrease the accuracy of logical reasoning (Białek et al., 2020; Mækelæ \& Pfuhl, 2019), or decrease mental imagery (Hayakawa \& Keysar, 2018; but see MonteroMelis et al., 2020 for a discussion). Finally, using a foreign language affects moral judgments by decreasing the impact of relevant moral intuitions (both deontological and utilitarian; Hayakawa et al., 2017; Muda et al., 2018), while not affecting generalized inaction tendency (Białek et al., 2019; but see Hennig \& Hütter, 2021 for a discussion). There are also several null findings regarding the foreign language effect in risk (Hayakawa et al., 2019; Muda, Pieńkosz, et al., 2020; Muda, Walker, et al., 2020).

Hayakawa and colleagues (2016) proposed three mechanisms responsible for the foreign language effect: reduced affective response, increased cognitive engagement, and use of more 
abstract construals. None of these mechanisms received convincing support, and some have been discredited, e.g., by showing that emotions do not mediate the foreign language effect (Geipel et al., 2015), or that the processing in L2 does not increase performance in the cognitive reflection test, with the direction of the differences actually favoring L1 performers (Białek et al., 2019; Costa et al., 2014). A more recent model proposes that using L2 affects metacognition (Białek et al., 2020). In the dual-process theories of cognition, people have two types of cognitive processes: intuitions they generate automatically in response to triggering stimuli, and reflection they engage in when intuitions are in conflict (Evans \& Stanovich, 2013; Pennycook et al., 2015). Intuitions cue responding, if only one intuition is available or if it is much more salient than the other intuitions; intuitions cue reflection, if multiple intuitions of similar saliency are available, or when no intuition is produced (Ackerman \& Thompson, 2017; De Neys \& Pennycook, 2019).

Białek and colleagues (2020) studied logical reasoning and observed that people using L2 were less accurate in deciding when to trigger reflection: they reflected when a salient accurate intuition was available or refrained from reflecting when intuitions were inaccurate. The exact mechanism of how L2 affects metacognition is unknown: it can either stun intuitions or increase the conflict-threshold for reflection to trigger. Either way, in L2, individuals fail to take advantage of their intuition: they deliberate when a correct response is salient, thus risking computational errors, or they fail to engage in required reflection when the intuition was incorrect. Consistent with this framework, other research on the foreign language effect has been shown to work mostly when one response is intuitively appealing and incorrect, as in the framing effect or in moral judgments (Circi et al., 2021). If using L2, in fact, affects metacognition, we would expect this to also affect the bias blind spot. This would be yet another instance when distorting metacognition is actually beneficial, as it minimizes access to faulty, intuitive conclusions ("I am less prone to this bias than others"). Intuition may favor assigning more bias to others and less bias to oneself. Stunting these intuitions in L2 could reduce this misattribution, and in turn reduce the bias blind spot. Alternatively, L2 can hamper reflection about how others are susceptible to a bias. If L2 could reduce reflection, this would have a paradoxical effect of reducing the bias blind spot, because self and other appraisals would be made with similar cognitive processes. In sum, altering metacognition in L2 should attenuate the bias blind spot.

\section{Experiment 1}

\subsection{Participants}

We recruited Prolific (Palan \& Schitter, 2018) participants who met the following criteria: (1) they were residents of Poland, (2) their first language was Polish, and (3) they had at least 98\% of tasks approved. We aimed to have 200 participants in each condition to achieve $80 \%$ power to detect effects as small as $d=.25$, smaller than $d>.30$ observed in studies on the foreign language effect (Circi et al., 2021; Stankovic et al., 2022). We collected data from 500 participants $\left(400 / .8 ; N_{\mathrm{L} 1}=249, N_{\mathrm{L} 2}=251\right)$ because we expected a $\sim 20 \%$ exclusion rate of participants who were either inattentive - based on a single-choice attention check - or presented an insufficient self-rated understanding of the bias descriptions (below 5 on a scale of 1 to 10$)$.

Ultimately, the preregistered exclusions eliminated a larger-than-expected number of participants (166 participants, or 33.2\% of the entire sample), leaving 334 participants in the final analysis $\left(N_{\mathrm{L} 1}=153, N_{\mathrm{L} 2}=181\right)$. The gender composition of our sample was $68.3 \%$ male, $29.9 \%$ female, and $1.8 \%$ non-binary or undisclosed. The mean age of participants was 23.7 years $(S D=7.1)$. Participants that were in the $\mathrm{L} 2$ condition rated their proficiency in the second language as lower than participants in the $\mathrm{L} 1$ condition $\left(M_{\mathrm{L} 1}=8.15, S D=1.36, M_{\mathrm{L} 2}=7.79, S D\right.$ 
$=1.36, t=2.41, p=.016$ ). This is most likely due to the confidence in their L2 proficiency level being attenuated after conducting the entire experiment in L2.

\subsection{Materials and methods}

In this experiment, we preregistered and employed a mixed design: we manipulated language between-subjects, while the object of the rating (oneself or the average person) was a withinsubjects factor. Participants were randomly assigned to the L1 condition (Polish) or the L2 condition (English). Their task was to assess to what extent they are susceptible to a given bias, and what is the susceptibility of an average Pole (i.e., the participants' countryman) to the same bias, using a scale of 1 (not at all) to 7 (very much).

To make our investigation more insightful, we extend the list of biases that could be subject to the bias blind spot. Apart from the use of numerous biases uncovered by psychological research, we also use a series of biases that have been uncovered by economists. We used 13 psychological biases from previous research on the bias blind spot (Scopelliti et al., 2015), and 7 economic biases that we selected for this study. These 20 biases were presented in a random order to every participant. See Table S1 in the Supplementary Materials for the description of the biases, in both languages.

The dependent variable was defined as the difference between the estimate of the susceptibility to the bias of an average Pole and the estimated susceptibility of the participant to the same bias. Positive values suggest that people find that others are more susceptible to a bias than themselves, confirming the bias blind spot. If a random person recruited in this study thought they are equally susceptible to the bias as a random person not recruited to the study, the mean bias would be zero. Negative values, however, would suggest that a participant thought that they were more biased than an average person.

Given that for every participant we calculated 20 such difference scores, we decided to perform a series of linear mixed-effects models, with the language of presentation and the type of bias (psychological or economic) serving as fixed effects. As random effects, we entered intercepts for participants and biases. In separate regressions, we investigated the potential interaction effect between language and type of bias (although we had no predictions regarding the strength of the bias blind spot in these cases) and controlled for the gender, age (logged), and education level of participants.

This study was pre-registered at: https://aspredicted.org/e4cg8.pdf. We made one deviation from the preregistration: due to a coding error, we have not collected data for one bias (the ostrich effect) in the L2 condition, and thus investigated 13 psychological biases instead of the 14 biases used in Scopelliti et al. (2015). Data and materials are available at: https://osf.io/j43df/.

Informed consent was obtained from all participants, and the study adhered to appropriate ethical guidelines.

\subsection{Results}

\subsubsection{Preregistered analysis}

Our data confirmed the existence of a bias blind spot: participants stated that they were less susceptible to a bias than the average person from their country (Poland), $M_{\text {bias blind spot }}=1.55$, $95 \% C I=[1.46,1.64], S D=0.83, t=34.2, p<.001$. The bias blind spot was more pronounced in psychological biases than in economic biases $\left(M_{\text {psychological }}=1.77, S D=1.00, M_{\text {economic }}=1.13\right.$, $S D=0.80$; see Figure 1, Panel A). 
Crucially, we did not find convincing evidence for the main effect of language in reducing the bias blind spot, but a type-of-bias-by-language interaction (discussed later on): the bias blind spot was reduced when using L2 in psychological biases $\left(M_{\text {psychological-L1 }}=1.87, S D=0.96\right.$, $\left.M_{\text {psychological-L2 }}=1.69, S D=1.03\right)$, but not in economic biases $\left(M_{\text {economic-L1 }}=1.12, S D=0.81\right.$, $\left.M_{\text {economic-L2 }}=1.13, S D=0.79\right)$. The bias blind spot decreased in L2 because people thought others are less biased, rather than because they thought to be more biased themselves (Figure 1, Panel B). Still, the effect of using L2 was rather small, with the difference between self and others' susceptibility to the bias decreasing by a mere 0.18-points (versus a 1.6-point bias blind spot in L1). 
A

Bias blind spot

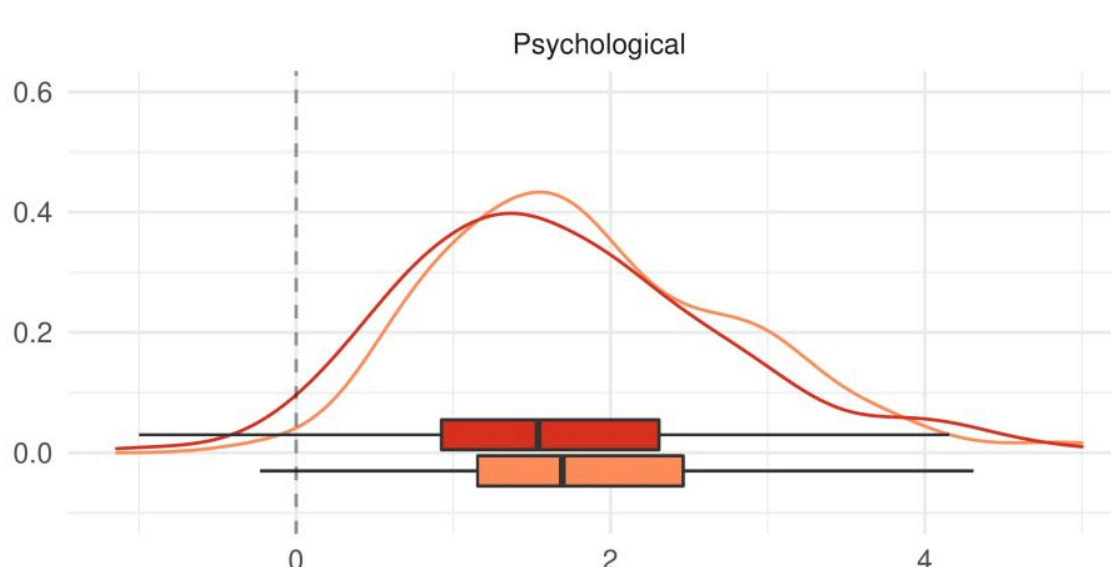

B

Psychological

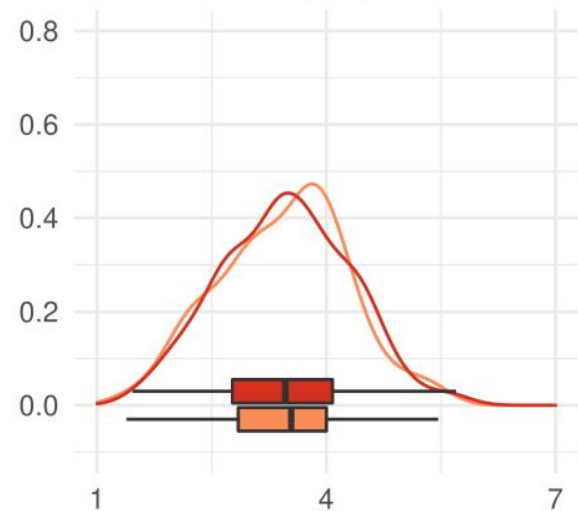

Susceptibility: me

Economic

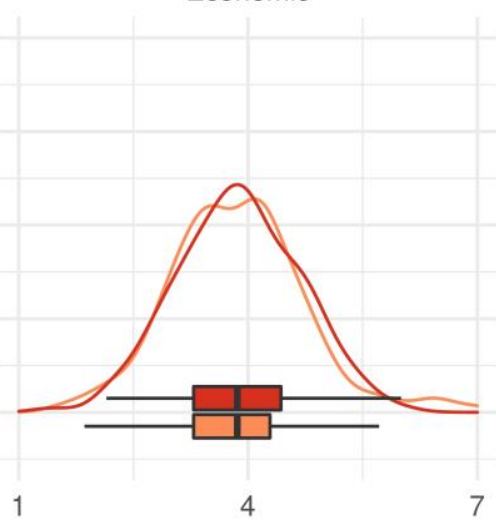

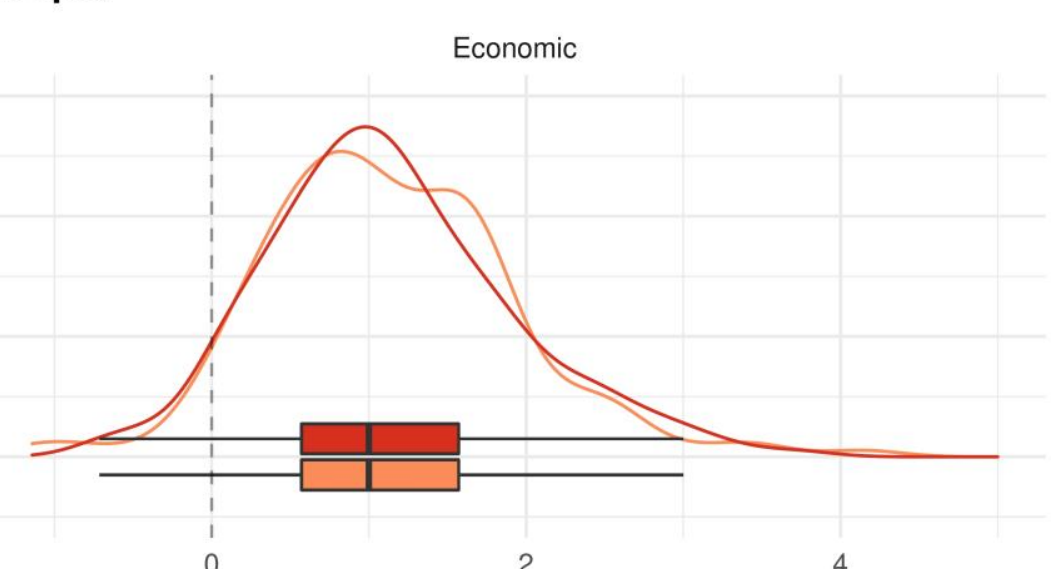

Susceptibility: others

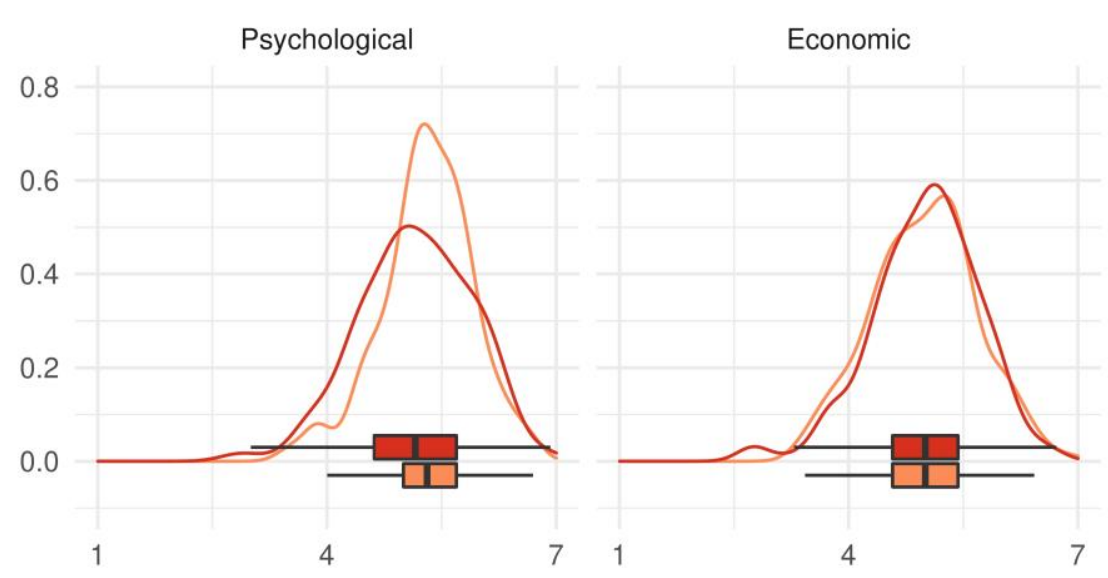

\section{宁 L1 宁 L2}

Figure 1. Bias blind spot and susceptibility of self and others to biases: Experiment 1

Notes: Colored lines correspond to density plots for average responses within each bias type. The bias blind spot is shown in Panel A. It is computed as the difference between susceptibility of others and susceptibility of oneself, which are shown in Panel B. 
We conducted a formal test of the effect of the language of presentation and bias type via preregistered mixed-model regressions (Table 1). Looking at all the biases, the use of L2 instead of L1 did not decrease the bias blind spot $(b=-0.11, S E=0.09, p=.213)$. However, we anticipated the possibility of significant differences between how people will judge the susceptibility to psychological and economic biases, and thus also preregistered regressions containing language $(0=\mathrm{L} 1,1=\mathrm{L} 2) \times$ bias type $(0=$ psychological, $1=$ economic $)$ interactions. Models containing these interactions and controls are shown in the 'Full model' columns. Estimates from a sample using the preregistered exclusions are consistent (albeit statistically non-significantly) with the hypothesized attenuation-in-L2-effect for the bias blind spot. While people showed a lower blind spot if the descriptions of psychological biases were presented in their second language and not their first language, the effect was nullified for economic biases. A simple explanation for this difference is that because people exhibited a lower blind spot for economic than psychological biases $(b=0.74, S E=0.28, p=.007)$, it left much less space for the effect of L2 to operate. Hence, it is easier to reduce a more prominent bias (i.e., psychological rather than economical).

One issue with our analysis is that we excluded a much larger number of individuals than expected: almost every third person failed to answer our comprehension question (where they had to select the bias that was not presented to them. Given that participants were shown 20 biases, we might have unnecessarily excluded a large number of attentive participants who were simply unable to memorize all 20 biases that they have rated. Being aware of this possibility beforehand, we preregistered an alternative analysis, with only self-reported proficiency in L2 used as a (more lenient) exclusionary criterion (see column "Secondary exclusion criteria" in Table 1). These results confirmed key earlier findings. The attenuation effect of L 2 was present, but only for psychological biases. The effect was significantly different for economic biases, essentially pointing to the lack of an attenuation of the bias blind spot for economic biases.

Table 1. Predictors of bias blind spot: Experiment 1

\begin{tabular}{lcccc}
\hline & \multicolumn{2}{c}{$\begin{array}{c}\text { Primary } \\
\text { exclusion criteria }\end{array}$} & \multicolumn{2}{c}{$\begin{array}{c}\text { Secondary } \\
\text { exclusion criteria }\end{array}$} \\
\hline & Reduced model & Full model & Reduced model & Full model \\
\hline Intercept) & $1.83^{* * * *}$ & $2.60^{* * *}$ & $1.81^{* * *}$ & $1.96^{* *}$ \\
L2 & $(0.17)$ & $(0.79)$ & $(0.16)$ & $(0.69)$ \\
& -0.11 & $-0.18^{\dagger}$ & -0.11 & $-0.20^{*}$ \\
Economic bias & $(0.09)$ & $(0.09)$ & $(0.08)$ & $(0.08)$ \\
& $-0.65^{*}$ & $-0.74^{* *}$ & $-0.65^{*}$ & $-0.76^{* *}$ \\
L2 $\times$ economic bias & $(0.27)$ & $(0.28)$ & $(0.26)$ & $(0.26)$ \\
& & $0.18^{*}$ & & $0.23^{* * *}$ \\
Age (logged) & & $(0.08)$ & & $(0.07)$ \\
& & -0.10 & & 0.04 \\
Gender: male & & $(0.23)$ & & $(0.21)$ \\
Gender: other & & -0.15 & & $-0.22^{* *}$ \\
& & $(0.10)$ & & $(0.08)$ \\
Gender: not specified & & 0.08 & & 0.15 \\
& & $(0.38)$ & & $(0.33)$ \\
Education: doctoral & -0.16 & & -0.21 \\
& & $(0.82)$ & & $(0.85)$ \\
& & 0.03 & & -0.37 \\
& & $(0.43)$ & & $(0.36)$
\end{tabular}




\begin{tabular}{|c|c|c|c|c|}
\hline & \multicolumn{2}{|c|}{$\begin{array}{c}\text { Primary } \\
\text { exclusion criteria }\end{array}$} & \multicolumn{2}{|c|}{$\begin{array}{c}\text { Secondary } \\
\text { exclusion criteria }\end{array}$} \\
\hline & Reduced model & Full model & Reduced model & Full model \\
\hline Education: masters & & $\begin{array}{l}-0.54^{* *} \\
(0.18)\end{array}$ & & $\begin{array}{l}-0.19 \\
(0.15)\end{array}$ \\
\hline Education: primary & & $\begin{array}{l}-0.39 \\
(0.28)\end{array}$ & & $\begin{array}{l}-0.11 \\
(0.22)\end{array}$ \\
\hline Education: secondary & & $\begin{array}{l}-0.38^{* *} \\
(0.13)\end{array}$ & & $\begin{array}{l}-0.08 \\
(0.11)\end{array}$ \\
\hline \multicolumn{5}{|l|}{ Random Effects } \\
\hline$\sigma^{2}$ & 2.36 & 2.36 & 2.49 & 2.49 \\
\hline \multirow[t]{2}{*}{$\tau_{00}$} & 0.57 participant & 0.55 participant & 0.59 participant & 0.59 participant \\
\hline & 0.33 bias & 0.33 bias & 0.30 bias & $0.30_{\text {bias }}$ \\
\hline ICC & 0.28 & 0.27 & 0.26 & 0.26 \\
\hline \multirow[t]{2}{*}{$\mathrm{N}$} & 334 participant & 334 participant & 491 participant & 491 participant \\
\hline & $20_{\text {bias }}$ & 20 bias & 20 bias & $20_{\text {bias }}$ \\
\hline Observations & 6680 & 6680 & 9820 & 9820 \\
\hline $\begin{array}{l}\text { Marginal } \mathrm{R}^{2} \text { / Conditional } \\
\mathrm{R}^{2}\end{array}$ & $0.029 / 0.297$ & $0.039 / 0.300$ & $0.028 / 0.284$ & $0.033 / 0.288$ \\
\hline
\end{tabular}

Notes: Both exclusion criteria were preregistered. The reference group for gender is female, and the reference group for education is a bachelor's degree, and thus the intercepts correspond to the bias blind spot for females with a bachelor's degree. Standard errors are in parentheses.

${ }^{\dagger} p=.052, * p<.05, * * p<.01, * * * p<.001$.

\subsubsection{Exploratory analysis}

For exploratory purposes, we investigated the bias blind spot and how it depended on the language of presentation individually for each of the 20 biases. Results are presented in Figure 2. There were significant differences in blind spots, ranging from a median blind spot of 3 points on a 7-point scale for stereotyping, to no blind spot for three economic biases (loss aversion, disposition effect, and mental accounting). 
A

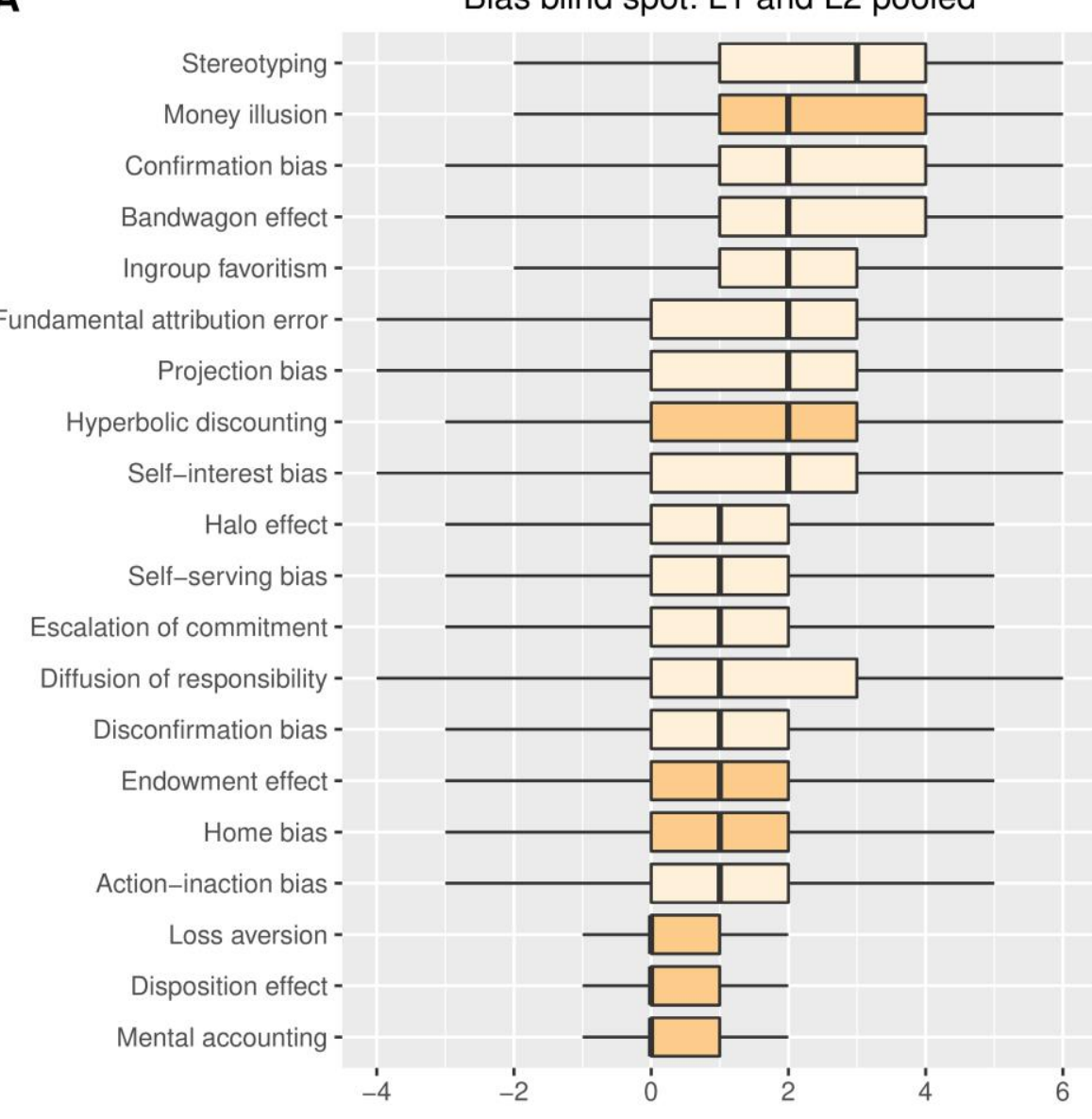

追 Psychological 追 Economic
B
Stereotyping -
Money illusion -
Confirmation bias -
Bandwagon effect -
Ingroup favoritism -
Fundamental attribution error -
Projection bias -
Hyperbolic discounting -
Self-interest bias -
Halo effect -
Self-serving bias -
Escalation of commitment -
Diffusion of responsibility -
Disconfirmation bias -
Endowment effect -
Home bias -
Action-inaction bias -
Loss aversion -
Disposition effect -
Mental accounting

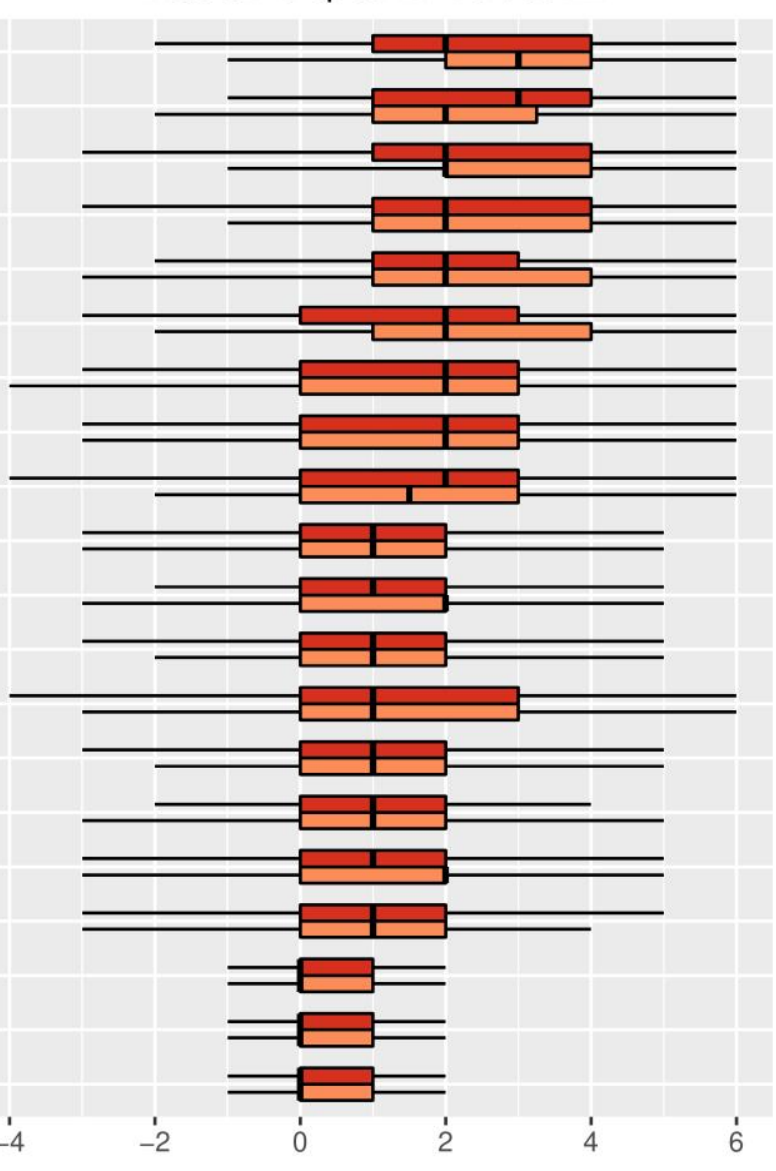

宁 L1 白 L2

Figure 2. Bias blind spot across biases: Experiment 1

Notes: Biases are presented based on the magnitude of the bias blind spot, in descending order. 


\subsection{Discussion}

In Experiment 1, we showed that the bias blind spot can be mitigated by using L2. Unexpectedly, this attenuation was only present for psychological biases, but not in economic biases. The simplest reason for this difference is that some economic biases failed to produce a bias blind spot. That is, for biases such as mental accounting, the disposition effect, or loss aversion, the median difference between perceived susceptibility of oneself and others was zero. There are two plausible explanations for this finding. Firstly, people might feel less confident when judging economic phenomena than psychological phenomena. If so, they will not necessarily think that they are better than the average person in this task. If a task is perceived to be more difficult, the blind spot can even reverse, so that a person sees themselves as more susceptible to a bias than an average person (Moore \& Healy, 2008; Pronin et al., 2002). Secondly, some economic biases may not be seen as biases, but as rational adaptations to the environment. A relevant finding is that people want to punish others who fail to show loss aversion (Dorison \& Heller, 2022), suggesting that loss aversion might seem to be socially desirable behavior. Hence, for some biases, no bias blind spot is expected, or people may even expect to show more of this "adaptive" behavior in themselves than in others.

This difference in the reduction of the bias blind spot between economic and psychological biases diluted the main effect of using a foreign language: if there is no bias, L2 cannot attenuate it. Finally, we lost many participants with our primary exclusion criteria $(\sim 33 \%)$ which limited our statistical power and could have rejected participants with some specific response patterns. The loss of participants, in turn, resulted in a marginally significant effect of language in psychological biases $(p=.052)$, which was significant with more liberal exclusion criteria. We decided to address these issues in Experiment 2.

\section{Experiment 2}

In this experiment, we decided to select 7 psychological biases that produced the largest bias blind spot in L1, to reinvestigate the attenuation-in-L2 effect. We also improved the control over the L2 proficiency of our participants.

\subsection{Participants}

After applying the same exclusionary criteria as in Experiment 1, we were left with 489 participants $\left(64.8 \%\right.$ male, $33.1 \%$ female, $2.0 \%$ other or undisclosed; $\left.M_{\text {age }}=23.6, S D=6.3\right)$ from the 500 we recruited. The smaller dropout (despite retaining the same comprehension question as in Experiment 1) is most likely observed because our participants now had to recognize a bias they have not rated from a set of 7 rather than 20 biases (as in Experiment 1). This way, the same question was much easier to pass while still ensuring a high quality of the data.

\subsection{Materials and procedure}

The procedure closely mirrored the one used in Experiment 1. We again manipulated language between-subjects and asked participants to rate both their own and others' susceptibility to a bias. We used seven biases in which the bias blind spot in L2 was the most prominent (i.e., disconfirmation bias, confirmation bias, fundamental attribution error, stereotyping, bandwagon effect, ingroup favoritism, projection bias).

The experiment was preregistered at: https://aspredicted.org/zd44s.pdf. Data and materials are available at: https://osf.io/j43df/. 


\subsection{Results}

\subsubsection{Language proficiency}

Objective measures of L2 proficiency were not different across conditions, likewise for age of acquisition $\left(M_{\mathrm{L} 1}=7.82, S D=3.90, M_{\mathrm{L} 2}=7.88, S D=3.52, t=0.17, p=.87\right)$, and the schoolleaving examination (Matura) score in English $\left(M_{\mathrm{L} 1}=78.5, S D=20.6, M_{\mathrm{L} 2}=79.0, S D=21.4\right.$, $t=0.24, p=.81$ ). Based on mean self-reported reading, writing, listening and speaking skills, participants rated themselves similarly proficient in L1 and L2 $\left(M_{\mathrm{L} 1}=6.12, S D=1.85, M_{\mathrm{L} 2}=\right.$ $\left.6.24, S D=0.95, t_{\text {paired }}=-1.89, p=.060\right)$; however, there might be a ceiling effect, with one indication of this being that the one-item L2 proficiency rating was only weakly correlated to the four-item score $(r=.118, p=.008)$.

\subsubsection{Preregistered analysis}

We again performed a linear mixed-model analysis. The bias blind spot in L2 users was reduced by 0.25 points ( 
Table 2). We also reanalyzed the data from Experiment 1 (with the stricter, primary exclusionary criteria) using only the seven most severe bias blind spots that were selected for Experiment 2. This analysis also confirmed a significant reduction of the bias blind spot in L2 users, by 0.36 points. Contrary to past research that found no gender differences in the bias blind spot (Pronin et al., 2002; Scopelliti et al., 2015), in both of our experiments, male participants were less prone to the bias blind spot compared to female participants. Figure 3 depicts the decrease in the bias blind spot in Experiments 1 and Experiment 2 in the seven most severe psychological biases. 
Table 2. Predictors of bias blind spot, susceptibility of oneself, and susceptibility of others for the most severe psychological biases, tested in both Experiments 1 and 2

\begin{tabular}{|c|c|c|c|c|c|}
\hline & \multicolumn{3}{|c|}{ Bias blind spot } & \multirow{2}{*}{$\begin{array}{c}\begin{array}{c}\text { Susceptibility: } \\
\text { me }\end{array} \\
\text { Pooled }\end{array}$} & \multirow{2}{*}{$\begin{array}{c}\begin{array}{c}\text { Susceptibility: } \\
\text { others }\end{array} \\
\text { Pooled }\end{array}$} \\
\hline & Pooled & $\begin{array}{c}\text { Experiment } \\
1 \\
\end{array}$ & $\begin{array}{c}\text { Experiment } \\
2 \\
\end{array}$ & & \\
\hline (Intercept) & $\begin{array}{l}3.22^{* * *} \\
(0.71)\end{array}$ & $\begin{array}{l}3.72^{* * * *} \\
(1.11)\end{array}$ & $\begin{array}{l}2.90^{* *} \\
(0.91)\end{array}$ & $\begin{array}{l}2.38^{* * * *} \\
(0.58)\end{array}$ & $\begin{array}{l}5.61^{* * * *} \\
(0.48)\end{array}$ \\
\hline L2 & $\begin{array}{c}-0.31^{* * * *} \\
(0.08)\end{array}$ & $\begin{array}{l}-0.36^{* *} \\
(0.13)\end{array}$ & $\begin{array}{l}-0.25^{*} \\
(0.10)\end{array}$ & $\begin{array}{l}0.20^{* *} \\
(0.06)\end{array}$ & $\begin{array}{l}-0.11^{*} \\
(0.05)\end{array}$ \\
\hline Age (logged) & $\begin{array}{l}-0.24 \\
(0.21)\end{array}$ & $\begin{array}{l}-0.29 \\
(0.33)\end{array}$ & $\begin{array}{l}-0.21 \\
(0.27)\end{array}$ & $\begin{array}{c}0.16 \\
(0.17)\end{array}$ & $\begin{array}{l}-0.08 \\
(0.14)\end{array}$ \\
\hline Gender: male & $\begin{array}{c}-0.36^{* * * *} \\
(0.09)\end{array}$ & $\begin{array}{l}-0.36^{*} \\
(0.14)\end{array}$ & $\begin{array}{c}-0.36^{* * *} \\
(0.11)\end{array}$ & $\begin{array}{c}0.13 \\
(0.07)\end{array}$ & $\begin{array}{c}-0.23^{* * * *} \\
(0.06)\end{array}$ \\
\hline Gender: other & $\begin{array}{c}0.34 \\
(0.31)\end{array}$ & $\begin{array}{c}0.42 \\
(0.54)\end{array}$ & $\begin{array}{c}0.25 \\
(0.38)\end{array}$ & $\begin{array}{l}-0.22 \\
(0.25)\end{array}$ & $\begin{array}{c}0.12 \\
(0.21)\end{array}$ \\
\hline Gender: not specified & $\begin{array}{c}0.79 \\
(0.80)\end{array}$ & $\begin{array}{c}0.14 \\
(1.17)\end{array}$ & $\begin{array}{l}1.75 \\
(1.11)\end{array}$ & $\begin{array}{l}-0.34 \\
(0.65)\end{array}$ & $\begin{array}{c}0.46 \\
(0.54)\end{array}$ \\
\hline Education: doctoral & $\begin{array}{c}0.62 \\
(0.37)\end{array}$ & $\begin{array}{l}-0.02 \\
(0.60)\end{array}$ & $\begin{array}{l}1.02^{*} \\
(0.47)\end{array}$ & $\begin{array}{l}-0.36 \\
(0.30)\end{array}$ & $\begin{array}{c}0.26 \\
(0.25)\end{array}$ \\
\hline Education: masters & $\begin{array}{l}-0.03 \\
(0.15)\end{array}$ & $\begin{array}{l}-0.51^{*} \\
(0.25)\end{array}$ & $\begin{array}{c}0.26 \\
(0.18)\end{array}$ & $\begin{array}{c}0.05 \\
(0.12)\end{array}$ & $\begin{array}{c}0.02 \\
(0.10)\end{array}$ \\
\hline Education: primary & $\begin{array}{l}-0.05 \\
(0.25)\end{array}$ & $\begin{array}{l}-0.28 \\
(0.40)\end{array}$ & $\begin{array}{c}0.06 \\
(0.32)\end{array}$ & $\begin{array}{c}0.10 \\
(0.20)\end{array}$ & $\begin{array}{c}0.05 \\
(0.17)\end{array}$ \\
\hline Education: secondary & $\begin{array}{c}0.04 \\
(0.11)\end{array}$ & $\begin{array}{l}-0.36 \\
(0.18)\end{array}$ & $\begin{array}{l}0.30^{*} \\
(0.14)\end{array}$ & $\begin{array}{c}0.01 \\
(0.09)\end{array}$ & $\begin{array}{c}0.05 \\
(0.07)\end{array}$ \\
\hline \multicolumn{6}{|l|}{ Random Effects } \\
\hline$\sigma^{2}$ & 2.42 & 2.40 & 2.44 & 1.77 & 1.27 \\
\hline \multirow[t]{2}{*}{$\tau_{00}$} & 0.93 participant & $1.01_{\text {participant }}$ & 0.87 participant & 0.58 participant & 0.40 participant \\
\hline & 0.21 bias & 0.22 bias & 0.20 bias & 0.16 bias & 0.07 bias \\
\hline ICC & 0.32 & 0.34 & 0.31 & 0.30 & 0.27 \\
\hline \multirow[t]{2}{*}{$\mathrm{N}$} & 823 participant & 334 participant & 489 participant & 823 participant & 823 participant \\
\hline & 7 bias & 7 bias & 7 bias & 7 bias & 7 bias \\
\hline Observations & 5761 & 2338 & 3423 & 5761 & 5761 \\
\hline $\begin{array}{l}\text { Marginal } \mathrm{R}^{2} / \\
\text { Conditional } \mathrm{R}^{2}\end{array}$ & $\begin{array}{c}0.019 / \\
0.332\end{array}$ & $\begin{array}{c}0.023 / \\
0.353\end{array}$ & $\begin{array}{c}0.024 / \\
0.322\end{array}$ & $0.007 / 0.303$ & $0.010 / 0.275$ \\
\hline
\end{tabular}

Notes: The biases are the seven most severe psychological biases from Experiment 1. The effect of L2 is similar in models that exclude control variables, which have been omitted to enhance readability. The reference group for gender is female, and the reference group for education is a bachelor's degree, and thus the intercept corresponds to either the bias blind spot (columns 1-3) or the susceptibility ratings for oneself versus others (columns 4-5) of a female participant with a bachelor's degree.

Standard errors are in parentheses. $* p<.05, * * p<.01, * * * p<.001$. 


\section{Pooled data analysis}

We decided to run an additional test of the L2-effect on bias blind spot, by pooling the data from Experiments 1 and 2, but only using the 7 biases that were presented to participants in both experiments (selected due to the strong bias blind spot in the L1 condition of Experiment 1). This analysis (see Figure 3) again showed that people exhibit the bias blind spot in both languages, but that it is smaller in L2 users. This, we believe, is compelling evidence for the existence of an attenuating effect of L2 on the bias blind spot.

\section{Bias blind spot}

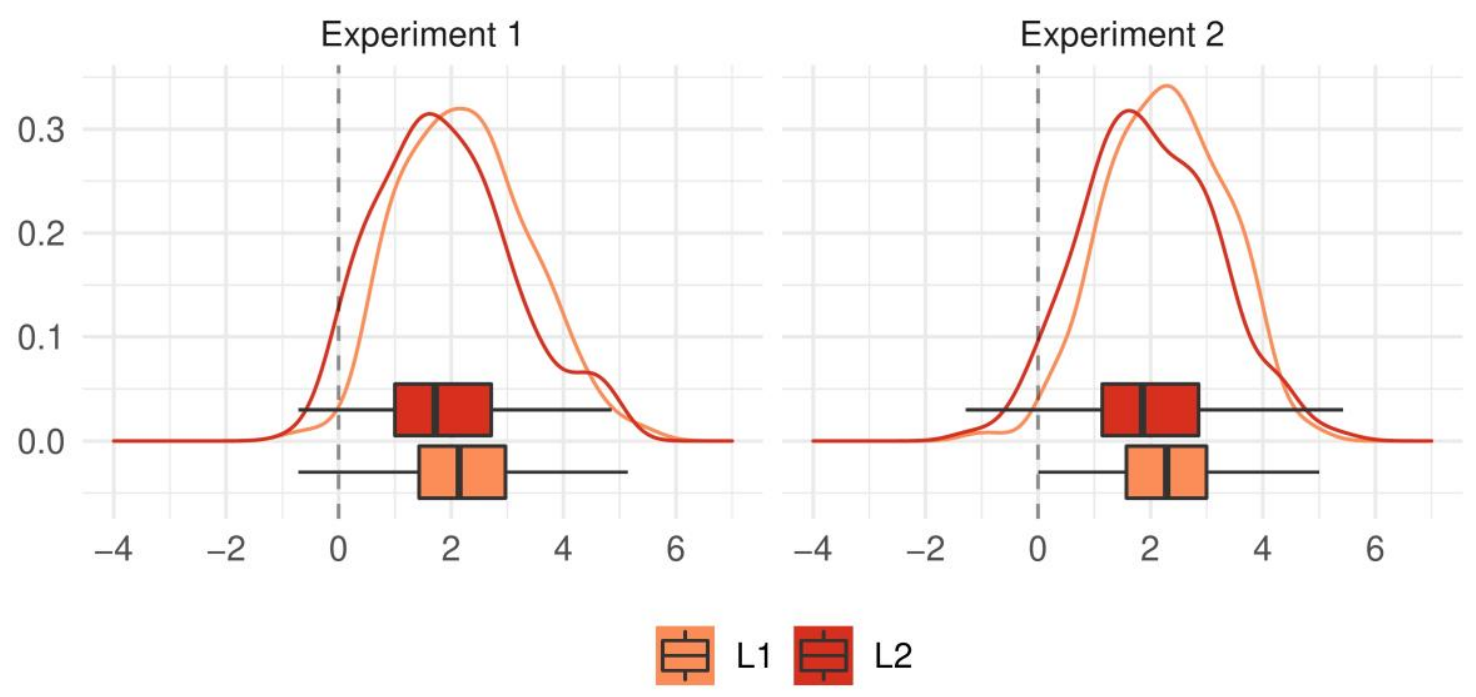

Figure 3. Bias blind spot in the most severe psychological biases

Notes: Colored lines correspond to density plots for average responses within each bias type. The biases are the seven most severe psychological biases from Experiment 1.

We also tested what exactly caused the reduction of the bias blind spot in L2 users: it could be that they perceived themselves as more biased, others as less biased, or both. To answer this question, we tested the pooled data from the seven biases that were included in both experiments. The two last columns in 
Table 2 show the results of a mixed-model analysis, with perceived self-susceptibility and perceived others-susceptibility as dependent variables. Both analyses showed a significant effect of language. That is to say, people not only found themselves to be more likely to be susceptible to a bias, but they also found others to be less susceptible to the same bias. For completeness, Figure 4 presents the effects for each bias individually (see Figure $\mathbf{S 1}$ in the Supplementary Materials for a similar illustration for the 20 biases used in Experiment 1).

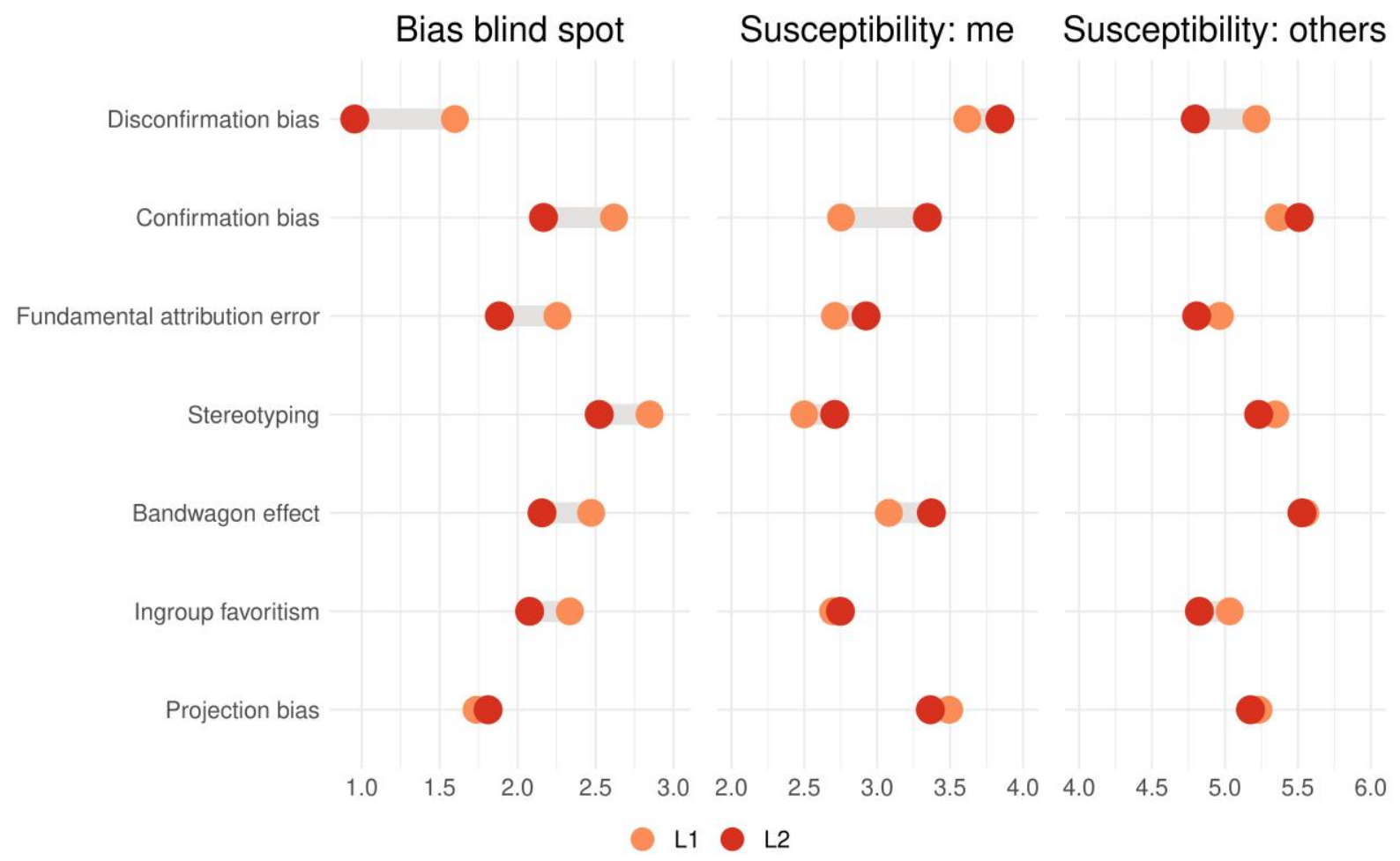

Figure 4. Changes to bias blind spot in $\mathrm{L} 1$ and $\mathrm{L2}$, and its decomposition into shifts in perceived self-susceptibility and others-susceptibility

Notes: Dots correspond to means computed across participants. Biases are presented based on the size of reduction of the blind spot in $\mathrm{L} 2$, in descending order.

\section{General Discussion}

Our two experiments (with 832 participants overall) showed that the bias blind spot is reduced when using L2 (in our case: English instead of Polish). The magnitude of the decrease is rather small, with the difference between perceived self-susceptibility and others-susceptibility decreasing by about 0.3 points, from 3.2 to 2.9 points on a 7 -point scale. The L2 (foreign language) effect on the bias blind spot effect was driven by both an increase in the perceived susceptibility of oneself to biased thinking, and a decreased perceived susceptibility to the same bias in others.

The magnitude of the decrease varies by bias, with the strongest shifts happening in biases revolving around prior beliefs, i.e., either the extensive scrutiny of contradictory evidence (disconfirmation bias; Edwards \& Smith, 1996), or the search for evidence that would confirm one's prior beliefs (confirmation bias; Wason, 1960). The reduction in bias blind spot was also prominent in cases where individuals over-emphasize dispositional factors when thinking about their own behavior, but over-emphasize personality-based factors when thinking about others' behavior (the fundamental attribution error; Ross, 1977). 
The current research is one of very few that point to how language affects metacognition: in L2, thinking about one's own cognition and the cognition of others becomes more similar. Metacognition is the main mechanism postulated to be responsible for biases in human cognition (Ackerman \& Thompson, 2017): people find it harder to see biases in their own thinking than in the thinking of others. To truly think, rather than rely on intuitions, one has to be able to detect that their own cognition may be biased and decide to invest additional mental resources to engage in reflection. Past research showed that this metacognitive tracking of one's own thinking can be distorted in L2 users, which in turn distorts the allocation of cognitive resources (Białek et al., 2020), e.g., by cueing reflection in tasks that otherwise produce convincing and accurate intuitive responses. This distorted metacognition can be beneficial in some tasks, e.g., when intuitions are known to be strong and misleading. Consistently with this account, we see that using a foreign language distorts metacognition, producing - paradoxically - more accurate comparative evaluations.

Similar results as the ones reported here can be predicted from a hypothesis that has not yet been directly tested, concerning changes in construal level when thinking in L1 vs L2 (Hayakawa et al., 2016). There are two types of construals - low-level and high-level construals (Trope \& Liberman, 2010). Higher-level construals are abstract, and represent generalized beliefs and thoughts about events psychologically, physically, or temporally distant. Abstract construals retain central features of an object but omit some item-specific information. To illustrate: a group of children chasing a ball could be "playing with a ball" (low-level construal), or "exercising" (high-level construal), with the latter omitting the information about the incidental details of the activity. If using L2 could shift thinking from concrete to abstract, it would help one to adopt a "birds-eye view" more easily, which is precisely what is missing in people judging how susceptible they themselves are to biases (relative to others). In plain words, the distance of the self and others - or the perceived difference in their perception - should be smaller from afar (the abstract level).

The value of our discovery is that we show that people using L2 changed how they perceive themselves and others without being additionally trained, not being provided with any additional information, and obviously without becoming more cognitively gifted. These changes made comparative assessments more accurate. This is critical since most cognitive psychologists and decision-making researchers seem to locate sources of biases in miserliness in cognition that promotes the use of fallacious heuristics, or in the lack of cognitive capacity to process the required information. With the current research, metacognition has been shown to (paradoxically) improve thanks to such a simple manipulation as presenting the problem in a second language. Hence, the source of the bias blind spot, and maybe all other biases, does not only stem from the lack of expertise or cognitive abilities; it also stems from faulty metacognition. We show that there is a potential to improve judgment and decision-making by affecting bilinguals' metacognition. Future research should look at whether it is possible to help monolinguals similarly. One hint that debiasing is possible comes from an alcohol and morality study (Paruzel-Czachura et al., 2021). This experiment had a cognitive reflection test as a control variable and reported that people who drank alcohol or thought they drank it (in a placebo condition) improved their performance in the test. Hence, maybe thinking that a task is harder (because it is presented in a foreign language, or because one believes to be impaired by alcohol) can improve how people metacognitively decide to allocate their sparse cognitive resources.

\section{Limitations}

A limitation of this study is that we used only one language pair (Polish-English). It is always a possibility that the effect we observed will not generalize beyond this pair or is unidirectional: 
maybe there are some features of the English language that make the bias blind spot less vivid. This is unlikely, however, since most of the past research observed the same foreign language effect regardless of which language pair was used (Białek et al., 2019; Costa et al., 2014), as long as the two languages do not share too great of a similarity, and there isn't too strong of an exposure to L2 via media (Dylman \& Champoux-Larsson, 2020).

In addition, we used an online experiment, in which participants could hypothetically machinetranslate the descriptions of the biases from their second to their first language. However, this would make our estimates more conservative, because these participants processed all the materials in their first language, and therefore would show no L2 (foreign language) effect at all.

Finally, while the attenuating effect of L2 appears to be robust in instances where the bias blind spot is strong in L1, the effects are small. At the same time, it is also difficult to predict whether the effects would be perhaps even smaller (or larger) outside of experimental settings. On the one hand, laboratory studies appear to predict real-world effects quite well (Mitchell, 2012), albeit effect sizes are often smaller outside of the lab. On the other hand, there are virtually no studies that investigate the foreign language effect in real-world scenarios, except for a study that allowed participants to select their compensation for participating in the experiment, between a certain payoff and a lottery (Keysar et al., 2012). Thus, it would be beneficial to validate key foreign language effects in more realistic settings.

\section{Conclusions}

Our findings suggest that bilinguals using L2 are less likely to erroneously assume that they are less susceptible to various psychological biases than other people. This suggests that bilinguals' metacognition changes when using L2. Crucially, given that metacognition is the cause of most if not all judgments and decision-making biases, this provides an avenue to improve people's performance. However, more research is needed to understand how using a foreign language affects (meta)cognition, and whether similar effects can be achieved in monolinguals using different means.

\section{Implications}

Bilinguals that heavily use their second language in everyday life (e.g., English in business meetings) might be more likely to assume that they are similarly susceptible to various psychological biases as other people. This will be beneficial, for example, when designing policies for the general public, as discussions in linguistically-diverse teams - in which many members will be communicating in their second language - will yield less biased estimates. Of course, all team members must be truly bilingual, as an insufficient command of the language used in the meeting will hamper discussions, and introduce several problems of its own (Piekkari et al., 2015). 


\section{References}

Ackerman, R., \& Thompson, V. A. (2017). Meta-Reasoning: Monitoring and Control of Thinking and Reasoning. Trends in Cognitive Sciences, 21(8), 607-617. https://doi.org/10.1016/j.tics.2017.05.004

Białek, M., Domurat, A., Paruzel-Czachura, M., \& Muda, R. (2022). Limits of the foreign language effect: Intertemporal choice. Thinking \& Reasoning, 28(1), 97-124. https://doi.org/10.1080/13546783.2021.1934899

Białek, M., Muda, R., Stewart, K., Niszczota, P., \& Pieńkosz, D. (2020). Thinking in a foreign language distorts allocation of cognitive effort: Evidence from reasoning. Cognition, 205, 104420. https://doi.org/10.1016/j.cognition.2020.104420

Białek, M., Paruzel-Czachura, M., \& Gawronski, B. (2019). Foreign language effects on moral dilemma judgments: An analysis using the CNI model. Journal of Experimental Social Psychology, 85, 103855. https://doi.org/10.1016/j.jesp.2019.103855

Circi, R., Gatti, D., Russo, V., \& Vecchi, T. (2021). The foreign language effect on decisionmaking: A meta-analysis. Psychonomic Bulletin \& Review, 28(4), 1131-1141. https://doi.org/10.3758/s13423-020-01871-z

Costa, A., Foucart, A., Arnon, I., Aparici, M., \& Apesteguia, J. (2014). "Piensa" twice: On the foreign language effect in decision making. Cognition, 130(2), 236-254.

De Neys, W., \& Pennycook, G. (2019). Logic, fast and slow: Advances in dual-process theorizing. Current Directions in Psychological Science, 28(5), 503-509.

Dorison, C. A., \& Heller, B. H. (2022). Observers penalize decision makers whose risk preferences are unaffected by loss-gain framing. Journal of Experimental Psychology: General. https://doi.org/10.1037/xge0001187

Dylman, A. S., \& Champoux-Larsson, M.-F. (2020). It's (not) all Greek to me: Boundaries of the foreign language effect. Cognition, 196, 104148. https://doi.org/10.1016/j.cognition.2019.104148

Edwards, K., \& Smith, E. E. (1996). A disconfirmation bias in the evaluation of arguments. Journal of Personality and Social Psychology, 71(1), 5-24. https://doi.org/10.1037/0022-3514.71.1.5

Evans, J. S. B. T., \& Stanovich, K. E. (2013). Dual-Process Theories of Higher Cognition: Advancing the Debate. Perspectives on Psychological Science, 8(3), 223-241. https://doi.org/10.1177/1745691612460685

Geipel, J., Hadjichristidis, C., \& Surian, L. (2015). The foreign language effect on moral judgment: The role of emotions and norms. PloS One, 10(7), e0131529, https://doi.org/10.1371/journal.pone.0131529.

Hadjichristidis, C., Geipel, J., \& Keysar, B. (2019). The influence of native language in shaping judgment and choice. In Progress in Brain Research. Elsevier. https://doi.org/10.1016/bs.pbr.2019.02.003

Hadjichristidis, C., Geipel, J., \& Savadori, L. (2015). The effect of foreign language in judgments of risk and benefit: The role of affect. Journal of Experimental Psychology: Applied, 21(2), 117-129. https://doi.org/10.1037/xap0000044

Hadjichristidis, C., Geipel, J., \& Surian, L. (2017). Breaking Magic: Foreign Language Suppresses Superstition. The Quarterly Journal of Experimental Psychology, 72(1), 18-28. https://doi.org/10.1080/17470218.2017.1371780

Hayakawa, S., Costa, A., Foucart, A., \& Keysar, B. (2016). Using a Foreign Language Changes Our Choices. Trends in Cognitive Sciences, 20(11), 791-793.

Hayakawa, S., \& Keysar, B. (2018). Using a foreign language reduces mental imagery. Cognition, 173, 8-15. https://doi.org/10.1016/j.cognition.2017.12.010 
Hayakawa, S., Lau, B. K. Y., Holtzmann, S., Costa, A., \& Keysar, B. (2019). On the reliability of the foreign language effect on risk-taking. Quarterly Journal of Experimental Psychology, 72(1), 29-40. https://doi.org/10.1177/1747021817742242

Hayakawa, S., Tannenbaum, D., Costa, A., Corey, J. D., \& Keysar, B. (2017). Thinking More or Feeling Less? Explaining the Foreign-Language Effect on Moral Judgment. Psychological Science, 28(10), 1387-1397. https://doi.org/10.1177/0956797617720944

Hennig, M., \& Hütter, M. (2021). Consequences, Norms, or Willingness to Interfere: A proCNI Model Analysis of the Foreign Language Effect in Moral Dilemma Judgment. Journal of Experimental Social Psychology, 95, 104148. https://doi.org/10.1016/j.jesp.2021.104148

Huang, H., \& Rau, P.-L. P. (2020). The first-second language influence on framing effects and loss aversion of balanced bilinguals. International Journal of Bilingualism, 24(2), 129-140. https://doi.org/10.1177/1367006918813646

Keysar, B., Hayakawa, S. L., \& An, S. G. (2012). The foreign-language effect: Thinking in a foreign tongue reduces decision biases. Psychological Science, 23(6), 661-668. https://doi.org/10.1177/0956797611432178

Mækelæ, M., \& Pfuhl, G. (2019). Deliberate reasoning is not affected by language. PLOS ONE, 14(1), e0211428. https://doi.org/10.1371/journal.pone.0211428

Mitchell, G. (2012). Revisiting Truth or Triviality: The External Validity of Research in the Psychological Laboratory. Perspectives on Psychological Science: A Journal of the Association for Psychological Science, 7(2), 109-117. https://doi.org/10.1177/1745691611432343

Montero-Melis, G., Isaksson, P., van Paridon, J., \& Ostarek, M. (2020). Does using a foreign language reduce mental imagery? Cognition, 196, 104134. https://doi.org/10.1016/j.cognition.2019.104134

Moore, D. A., \& Healy, P. J. (2008). The trouble with overconfidence. Psychological Review, 115(2), 502-517. https://doi.org/10.1037/0033-295X.115.2.502

Muda, R., Niszczota, P., Białek, M., \& Conway, P. (2018). Reading dilemmas in a foreign language reduces both deontological and utilitarian response tendencies. Journal of Experimental Psychology: Learning, Memory, and Cognition, 44(2), 321-326.

Muda, R., Pieńkosz, D., Francis, K., \& Białek, M. (2020). The moral foreign language effect is stable across presentation modalities. Quarterly Journal of Experimental Psychology, 73(11), 1930-1938. https://doi.org/10.1177/1747021820935072

Muda, R., Walker, A. C., Pieńkosz, D., Fugelsang, J. A., \& Białek, M. (2020). Foreign Language does not Affect Gambling-Related Judgments. Journal of Gambling Studies, 36(2), 633-652. https://doi.org/10.1007/s10899-020-09933-6

Palan, S., \& Schitter, C. (2018). Prolific.ac-A subject pool for online experiments. Journal of Behavioral and Experimental Finance, 17, 22-27. https://doi.org/10.1016/j.jbef.2017.12.004

Paruzel-Czachura, M., Pypno, K., Everett, J. A., Białek, M., \& Gawronski, B. (2021). The Drunk Utilitarian Revisited: Does Alcohol Really Increase Utilitarianism in Moral Judgment? Personality and Social Psychology Bulletin, 01461672211052120, https://doi.org/10.1177/01461672211052120

Pennycook, G., Fugelsang, J. A., \& Koehler, D. J. (2015). What makes us think? A threestage dual-process model of analytic engagement. Cognitive Psychology, 80, 34-72, https://doi.org/10.1016/j.cogpsych.2015.05.001

Piekkari, R., Oxelheim, L., \& Randøy, T. (2015). The Silent Board: How Language Diversity May Influence the Work Processes of Corporate Boards. Corporate Governance: An International Review, 23(1), 25-41. https://doi.org/10.1111/corg.12085 
Pronin, E., \& Kugler, M. B. (2007). Valuing thoughts, ignoring behavior: The introspection illusion as a source of the bias blind spot. Journal of Experimental Social Psychology, 43(4), 565-578. https://doi.org/10.1016/j.jesp.2006.05.011

Pronin, E., Lin, D. Y., \& Ross, L. (2002). The Bias Blind Spot: Perceptions of Bias in Self Versus Others. Personality and Social Psychology Bulletin, 28(3), 369-381. https://doi.org/10.1177/0146167202286008

Ross, L. (1977). The Intuitive Psychologist And His Shortcomings: Distortions in the Attribution Process. In L. Berkowitz (Ed.), Advances in Experimental Social Psychology (Vol. 10, pp. 173-220). Academic Press. https://doi.org/10.1016/S00652601(08)60357-3

Ross, L., \& Ward, A. (1995). Psychological Barriers to Dispute Resolution. In Advances in Experimental Social Psychology (Vol. 27, pp. 255-304). Elsevier. https://doi.org/10.1016/S0065-2601(08)60407-4

Scopelliti, I., Morewedge, C. K., McCormick, E., Min, H. L., Lebrecht, S., \& Kassam, K. S. (2015). Bias Blind Spot: Structure, Measurement, and Consequences. Management Science, 61(10), 2468-2486. https://doi.org/10.1287/mnsc. 2014.2096

Stankovic, M., Biedermann, B., \& Hamamura, T. (2022). Not all bilinguals are the same: A meta-analysis of the moral foreign language effect. Brain and Language, 227, 105082, https://doi.org/10.1016/j.bandl.2022.105082

Trope, Y., \& Liberman, N. (2010). Construal-level theory of psychological distance. Psychological Review, 117(2), 440-463. https://doi.org/10.1037/a0018963

Wason, P. C. (1960). On the Failure to Eliminate Hypotheses in a Conceptual Task. Quarterly Journal of Experimental Psychology, 12(3), 129-140. https://doi.org/10.1080/17470216008416717 


\section{Supplementary Materials \\ Bilinguals are less susceptible to the bias blind spot in their second language}

Table S1. List of psychological and economic biases

\begin{tabular}{|c|c|c|}
\hline Bias & Description in English & Description in Polish \\
\hline \multicolumn{3}{|c|}{ Psychological biases } \\
\hline $\begin{array}{l}\text { Action-inaction } \\
\text { bias }\end{array}$ & $\begin{array}{l}\text { People show a tendency to judge a } \\
\text { harmful action as worse than an } \\
\text { equally harmful inaction. For } \\
\text { example, this tendency leads to } \\
\text { thinking it is worse to falsely testify } \\
\text { in court that someone is guilty, than } \\
\text { not to testify that someone is } \\
\text { innocent. }\end{array}$ & $\begin{array}{l}\text { Ludzie wykazują tendencję do } \\
\text { oceniania szkodliwego działania } \\
\text { gorzej niż równie szkodliwej } \\
\text { bezczynności. Na przykład tendencja } \\
\text { ta prowadzi do myślenia, że fałszywe } \\
\text { zeznawanie w sądzie o czyjejś winie } \\
\text { będzie gorsze niż niezłożenie } \\
\text { zeznania, które by kogoś oczyściło z } \\
\text { zarzutów. }\end{array}$ \\
\hline $\begin{array}{l}\text { Bandwagon } \\
\text { effect* }\end{array}$ & $\begin{array}{l}\text { People show a tendency to do or } \\
\text { believe a thing only because many } \\
\text { other people believe or do that thing. } \\
\text { This makes them feel safer or to } \\
\text { avoid conflict. }\end{array}$ & $\begin{array}{l}\text { Ludzie wykazują tendencję do } \\
\text { robienia lub wierzenia w coś tylko } \\
\text { dlatego, że wielu innych ludzi w to } \\
\text { wierzy lub to robi. Robią tak aby czuć } \\
\text { się bezpieczniej lub aby uniknąć } \\
\text { konfliktu. }\end{array}$ \\
\hline $\begin{array}{l}\text { Confirmation } \\
\text { bias* }\end{array}$ & $\begin{array}{l}\text { People react to counterevidence by } \\
\text { actually strengthening their beliefs. } \\
\text { For example, when exposed to } \\
\text { negative evidence about their favorite } \\
\text { political candidate, people tend to } \\
\text { implicitly counterargue against that } \\
\text { evidence, therefore strengthening } \\
\text { their favorable feelings toward the } \\
\text { candidate. }\end{array}$ & $\begin{array}{l}\text { Przedstawienie dowodów, które } \\
\text { zaprzeczają czemuś w co ludzie } \\
\text { wierzą powoduje, że ludzie wręcz } \\
\text { wzmacniają wiarę w tą rzecz. Na } \\
\text { przykład, kiedy przedstawia się im } \\
\text { niekorzystne informacje o ich } \\
\text { ulubionym kandydacie politycznym, } \\
\text { ludzie mają tendencję do zaprzeczania } \\
\text { tym informacjom, co z kolei } \\
\text { powoduje wzmocnienie ich } \\
\text { pozytywnych odczuć wobec } \\
\text { kandydata. }\end{array}$ \\
\hline $\begin{array}{l}\text { Disconfirmation } \\
\text { bias* }\end{array}$ & $\begin{array}{l}\text { People show a "disconfirmation" } \\
\text { tendency in the way they evaluate } \\
\text { research about potentially dangerous } \\
\text { habits. That is, they are more critical } \\
\text { and skeptical in evaluating evidence } \\
\text { that an activity is dangerous when } \\
\text { they engage in that activity than when } \\
\text { they do not. }\end{array}$ & $\begin{array}{l}\text { Ludzie wykazują tendencję do } \\
\text { zaprzeczenia badaniom sugerującym, } \\
\text { że ich nawyki są niebezpieczne. } \\
\text { Oznacza to, że jeśli ludzie angażują } \\
\text { się w daną czynność, to są bardziej } \\
\text { krytyczni i sceptyczni wobec } \\
\text { dowodów sugerujących, że ta } \\
\text { czynność jest niebezpieczna niż wtedy } \\
\text { gdy w daną czynność się nie angażują. }\end{array}$ \\
\hline $\begin{array}{l}\text { Diffusion of } \\
\text { responsibility }\end{array}$ & $\begin{array}{l}\text { People tend not to help in an } \\
\text { emergency situation when other } \\
\text { people are present. This happens } \\
\text { because as the number of bystanders } \\
\text { increases, a bystander who sees other } \\
\text { people standing around is less likely } \\
\text { to interpret the incident as a problem, } \\
\text { and also is less likely to feel } \\
\text { individually responsible for taking } \\
\text { action. }\end{array}$ & $\begin{array}{l}\text { Ludzie mają tendencję do } \\
\text { nieudzielania pomocy w nagłym } \\
\text { wypadku, jeśli świadkami wypadku są } \\
\text { tez inni ludzie. Dzieje się tak, } \\
\text { ponieważ wraz ze wzrostem liczby } \\
\text { osób postronnych, osoba która widzi } \\
\text { inne osoby stojące w pobliżu jest } \\
\text { mniej skłonna zinterpretować } \\
\text { incydent jako problem, a także jest } \\
\text { mniej prawdopodobne, że poczuje się }\end{array}$ \\
\hline
\end{tabular}




\begin{tabular}{|c|c|c|}
\hline Bias & Description in English & Description in Polish \\
\hline & & $\begin{array}{l}\text { indywidualnie odpowiedzialna za } \\
\text { podjęcie działania. }\end{array}$ \\
\hline $\begin{array}{l}\text { Escalation of } \\
\text { commitment }\end{array}$ & $\begin{array}{l}\text { People will make irrational decisions } \\
\text { to justify actions they have already } \\
\text { taken. For example, when two people } \\
\text { engage in a bidding war for an object, } \\
\text { they can end up paying much more } \\
\text { than the object is worth to justify the } \\
\text { initial expenses associated with } \\
\text { bidding. }\end{array}$ & $\begin{array}{l}\text { Ludzie będą podejmować irracjonalne } \\
\text { decyzje, aby uzasadnić działania, } \\
\text { które już podjęli. Na przykład, gdy } \\
\text { dwie osoby licytują dany przedmiot, } \\
\text { mogą w końcu zapłacić znacznie } \\
\text { więcej niż przedmiot jest wart, aby } \\
\text { uzasadnić początkowe koszty } \\
\text { związane z licytacją. }\end{array}$ \\
\hline $\begin{array}{l}\text { Fundamental } \\
\text { attribution } \\
\text { error* }\end{array}$ & $\begin{array}{l}\text { People show a tendency to make } \\
\text { "overly dispositional inferences" in } \\
\text { the way they view victims of assault } \\
\text { crimes. That is, they are overly } \\
\text { inclined to view the victim's plight as } \\
\text { one he or she brought on by } \\
\text { carelessness, foolishness, } \\
\text { misbehavior, or naivetë. }\end{array}$ & $\begin{array}{l}\text { Ludzie wykazują tendencję do } \\
\text { „nadmiernie dyspozycyjnych } \\
\text { wniosków” w sposobie postrzegania } \\
\text { ofiar napaści. Oznacza to, że są } \\
\text { przesadnie skłonni do postrzegania } \\
\text { losu ofiary jako wywołanego ich } \\
\text { nieostrożnością, głupotą, złym } \\
\text { zachowaniem lub naiwnością. }\end{array}$ \\
\hline Halo effect & $\begin{array}{l}\text { People show a "halo" effect in the } \\
\text { way they form impressions of } \\
\text { attractive people. For instance, when } \\
\text { it comes to assessing how nice, } \\
\text { interesting, or able someone is, } \\
\text { people tend to judge an attractive } \\
\text { person more positively than he or she } \\
\text { deserves. }\end{array}$ & $\begin{array}{l}\text { Ludzie wykazują efekt ,aureoli” } \\
\text { oceniając atrakcyjnych ludzi. Na } \\
\text { przykład, oceniając to jak bardzo ktoś } \\
\text { jest miły, interesujący lub zdolny, } \\
\text { ludzie zwykle oceniają atrakcyjną } \\
\text { osobę bardziej pozytywnie niż na to } \\
\text { zasługuje. }\end{array}$ \\
\hline $\begin{array}{l}\text { Ingroup } \\
\text { favoritism* }\end{array}$ & $\begin{array}{l}\text { People possess an unconscious, } \\
\text { automatic tendency to be less } \\
\text { generous to people of a different race } \\
\text { than to people of their race. This } \\
\text { tendency has been shown to affect the } \\
\text { behavior of everyone from doctors to } \\
\text { taxi drivers. }\end{array}$ & $\begin{array}{l}\text { Ludzie mają nieświadomą, } \\
\text { automatyczną tendencję do mniejszej } \\
\text { hojności dla ludzi innej rasy niż dla } \\
\text { ludzi ich rasy. Pokazano, że tendencja } \\
\text { ta wpływa na zachowanie każdego, od } \\
\text { lekarzy po taksówkarzy. }\end{array}$ \\
\hline Projection bias* & $\begin{array}{l}\text { People have the tendency to } \\
\text { underestimate the impact or the } \\
\text { strength of another person's feelings. } \\
\text { For example, people who have not } \\
\text { been victims of discrimination do not } \\
\text { really understand a victim's social } \\
\text { suffering and the emotional effects of } \\
\text { discrimination. }\end{array}$ & $\begin{array}{l}\text { Ludzie mają tendencję do } \\
\text { niedoceniania wpływu lub siły uczuć } \\
\text { innej osoby. Przykładowo, ludzie } \\
\text { którzy nie byli ofiarami dyskryminacji } \\
\text { tak naprawdę nie rozumieją cierpienia } \\
\text { i emocjonalnych skutków ofiary } \\
\text { dyskryminacji. }\end{array}$ \\
\hline Self-interest bias & $\begin{array}{l}\text { People show a "self-interest" effect in } \\
\text { the way they view political } \\
\text { candidates. That is, people's } \\
\text { assessments of qualifications, and } \\
\text { their judgments about the extent to } \\
\text { which particular candidates would } \\
\text { pursue policies good for the Polish } \\
\text { people as a whole, are influenced by } \\
\text { their feelings about whether the } \\
\text { candidates' policies would serve their } \\
\text { own particular interests. }\end{array}$ & $\begin{array}{l}\text { Ludzie wykazują efekt „własnego } \\
\text { interesu” w sposobie postrzegania } \\
\text { kandydatów na stanowiska polityczne. } \\
\text { Oznacza to, że ich oceny kwalifikacji } \\
\text { kandydatów, oraz ich opinie o tym, w } \\
\text { jakim stopniu poszczególni kandydaci } \\
\text { realizowaliby politykę dobrą dla } \\
\text { całego narodu polskiego, zależą od } \\
\text { ich odczuć dotyczących tego, czy } \\
\text { polityka kandydatów służy ich } \\
\text { własnym interesom. }\end{array}$ \\
\hline
\end{tabular}




\begin{tabular}{|c|c|c|}
\hline Bias & Description in English & Description in Polish \\
\hline Self-serving bias & $\begin{array}{l}\text { People show a "self-serving" } \\
\text { tendency in the way they view their } \\
\text { academic or job performance. That is, } \\
\text { they tend to take credit for success } \\
\text { but deny responsibility for failure. } \\
\text { They see their successes as the result } \\
\text { of personal qualities, like drive or } \\
\text { ability, but their failures as the result } \\
\text { of external factors, like unreasonable } \\
\text { work requirements or inadequate } \\
\text { instructions. }\end{array}$ & $\begin{array}{l}\text { Ludzie wykazują skłonność do } \\
\text { „egocentryzmu” w sposobie } \\
\text { postrzegania swoich wyników w } \\
\text { nauce lub w pracy. Oznacza to, że } \\
\text { mają tendencję do przypisywania } \\
\text { sobie sukcesu, ale zaprzeczania } \\
\text { odpowiedzialności za porażkę. } \\
\text { Postrzegają swoje sukcesy jako wynik } \\
\text { cech osobistych, takich jak } \\
\text { determinacja lub zdolności, ale swoje } \\
\text { niepowodzenia spostrzegają jako } \\
\text { wynik czynników zewnętrznych, } \\
\text { takich jak nieuzasadnione wymagania } \\
\text { w pracy lub nieodpowiednie } \\
\text { instrukcje. }\end{array}$ \\
\hline Stereotyping* & $\begin{array}{l}\text { Gender biases lead people to } \\
\text { associate men with technology and } \\
\text { women with housework. }\end{array}$ & $\begin{array}{l}\text { Uprzedzenia ze względu na płeć } \\
\text { powodują, że ludzie kojarzą mężczyzn } \\
\text { z technologią, a kobiety z pracami } \\
\text { domowymi. }\end{array}$ \\
\hline \multicolumn{3}{|c|}{ Economic biases } \\
\hline Disposition effect & $\begin{array}{l}\text { Investors' show reluctance to sell } \\
\text { assets (e.g., stocks) that have lost } \\
\text { value, and willingness to sell assets } \\
\text { that have made gains. }\end{array}$ & $\begin{array}{l}\text { Inwestorzy wykazują niechęć do } \\
\text { sprzedaży aktywów (np. akcji), które } \\
\text { straciły na wartości a skłonność do } \\
\text { sprzedaży aktywów, które przyniosły } \\
\text { zyski. }\end{array}$ \\
\hline $\begin{array}{l}\text { Endowment } \\
\text { effect }\end{array}$ & $\begin{array}{l}\text { People tend to value items that they } \\
\text { own more highly than they would if } \\
\text { they did not belong to them. This } \\
\text { means that sellers often try to charge } \\
\text { more for an item than it would cost } \\
\text { elsewhere. Let's say a few months } \\
\text { ago, you bought a concert ticket for } \\
100 \text { zł. You just found out that you } \\
\text { won't be able to make it to the } \\
\text { concert after all, so you decide to } \\
\text { resell your ticket. You price the ticket } \\
\text { at } 150 \text { zł, because just selling it at } \\
\text { market value would feel like you } \\
\text { were losing out. }\end{array}$ & $\begin{array}{l}\text { Ludzie bardziej cenią wartość } \\
\text { przedmiotów tylko dlatego, że je } \\
\text { posiadają. Oznacza to, że sprzedawcy } \\
\text { często próbują naliczyć więcej za } \\
\text { przedmiot, niż kosztowałby gdzie } \\
\text { indziej. Powiedzmy, że kilka miesięcy } \\
\text { temu kupiłeś bilet na koncert za } 100 \\
\text { zł. Właśnie dowiedziałeś się, że mimo } \\
\text { wszystko nie uda Ci się dotrzeć na } \\
\text { koncert, więc decydujesz się } \\
\text { odsprzedać bilet. Wyceniasz bilet na } \\
150 \text { zł, ponieważ samo sprzedanie go } \\
\text { po cenie rynkowej mogłoby wywołać } \\
\text { poczucie straty. }\end{array}$ \\
\hline Home bias & $\begin{array}{l}\text { People invest the majority of their } \\
\text { portfolio in domestic equities } \\
\text { (stocks), ignoring the benefits of } \\
\text { investment in foreign equities } \\
\text { (stocks), i.e. diversification. }\end{array}$ & $\begin{array}{l}\text { Ludzie inwestują większość swojego } \\
\text { portfela w krajowe akcje, ignorując } \\
\text { korzyści płynące z inwestowania w } \\
\text { zagraniczne akcje tj. dywersyfikację. }\end{array}$ \\
\hline $\begin{array}{l}\text { Hyperbolic } \\
\text { discounting }\end{array}$ & $\begin{array}{l}\text { People have an inclination to choose } \\
\text { immediate rewards over rewards that } \\
\text { come later in the future, even when } \\
\text { these immediate rewards are smaller. }\end{array}$ & $\begin{array}{l}\text { Ludzie mają skłonność do wybierania } \\
\text { nagród natychmiastowych zamiast } \\
\text { nagród, które nadejdą później w } \\
\text { przyszłości, nawet jeśli te } \\
\text { natychmiastowe nagrody są mniejsze. }\end{array}$ \\
\hline Loss aversion & $\begin{array}{l}\text { For people the pain of losing is } \\
\text { psychologically (roughly) twice as } \\
\text { powerful as the pleasure of gaining. } \\
\text { In other words, the loss felt from }\end{array}$ & $\begin{array}{l}\text { Dla ludzi ból związany z przegraną } \\
\text { jest (w przybliżeniu) dwa razy } \\
\text { silniejszy od przyjemności } \\
\text { wynikającej z wygranej. Innymi }\end{array}$ \\
\hline
\end{tabular}




\begin{tabular}{|l|l|l|}
\hline \multicolumn{1}{|c|}{ Bias } & \multicolumn{1}{|c|}{ Description in English } & \multicolumn{1}{c|}{ Description in Polish } \\
\hline $\begin{array}{l}\text { money, or any other valuable object, } \\
\text { can feel worse than gaining that same } \\
\text { thing. Loss aversion refers to an } \\
\text { individual's tendency to prefer } \\
\text { avoiding losses to acquiring } \\
\text { equivalent gains. Simply put, it's } \\
\text { better not to lose 20 zł, than to find } \\
\text { 20 zł. }\end{array}$ & $\begin{array}{l}\text { słowy, strata pieniędzy lub innego } \\
\text { cennego przedmiotu może wydawać } \\
\text { się gorsza niż zdobycie tego samego. } \\
\text { Niechęć do straty odnosi się do } \\
\text { skłonności jednostki do preferowania } \\
\text { unikania strat niż uzyskiwania } \\
\text { równoważnych zysków. Mówiąc } \\
\text { najprościej, lepiej nie stracić 20 zł niż } \\
\text { znaleźć 20 zł. }\end{array}$ \\
\hline $\begin{array}{l}\text { Mental } \\
\text { accounting }\end{array}$ & $\begin{array}{l}\text { People tend to assign subjective value } \\
\text { to money, usually in ways that violate } \\
\text { basic economic principles. Although } \\
\text { money has consistent, objective } \\
\text { value, the way we go about spending } \\
\text { it is often subject to different rules, } \\
\text { depending on how we earned the } \\
\text { money, how we intend to use it, and } \\
\text { how it makes us feel. }\end{array}$ & $\begin{array}{l}\text { Ludzie przypisują subiektywną } \\
\text { wartość pieniądzom, zwykle w } \\
\text { sposób, który narusza podstawowe } \\
\text { zasady ekonomiczne. Chociaż } \\
\text { pieniądze mają stałą, obiektywną } \\
\text { wartość, sposób ich wydawania często } \\
\text { podlega innym zasadom, w zależności } \\
\text { od tego, jak zarobiliśmy pieniądze, jak } \\
\text { zamierzamy je wykorzystać i jak się z } \\
\text { tym czujemy. }\end{array}$ \\
\hline Money illusion & $\begin{array}{l}\text { People tend to view their wealth and } \\
\text { income in nominal terms, rather than } \\
\text { in real terms. In other words, it is } \\
\text { assumed that people do not take into } \\
\text { account the level of inflation in an } \\
\text { economy, wrongly believing that the } \\
\text { Polish złoty is worth the same as it } \\
\text { was the prior year. }\end{array}$ & $\begin{array}{l}\text { Ludzie mają tendencję do } \\
\text { postrzegania swojego majątku i } \\
\text { dochodów w ujęciu nominalnym, a } \\
\text { nie w ujęciu realnym. Innymi słowy, } \\
\text { zakłada się, że ludzie nie biorą pod } \\
\text { uwagę poziomu inflacji w gospodarce, } \\
\text { błędnie wierząc, że złotówka jest } \\
\text { warta tyle, co rok wcześniej. }\end{array}$ \\
\hline
\end{tabular}

Notes: Biases with an asterisk are biases used in Experiment 2. 
A

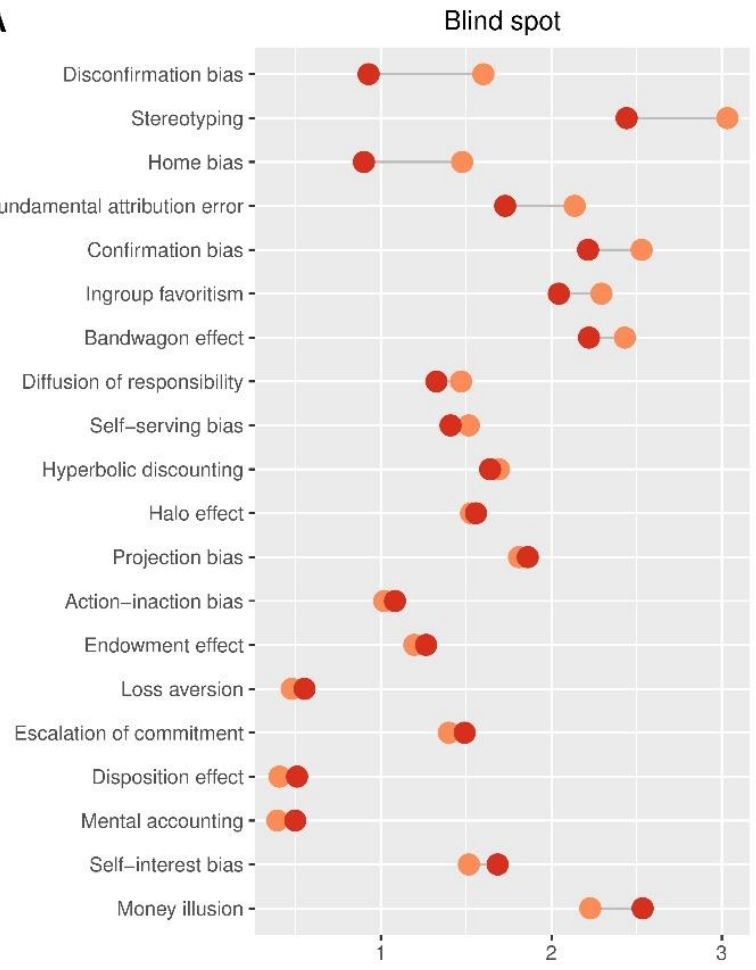

B

Susceptibility: me

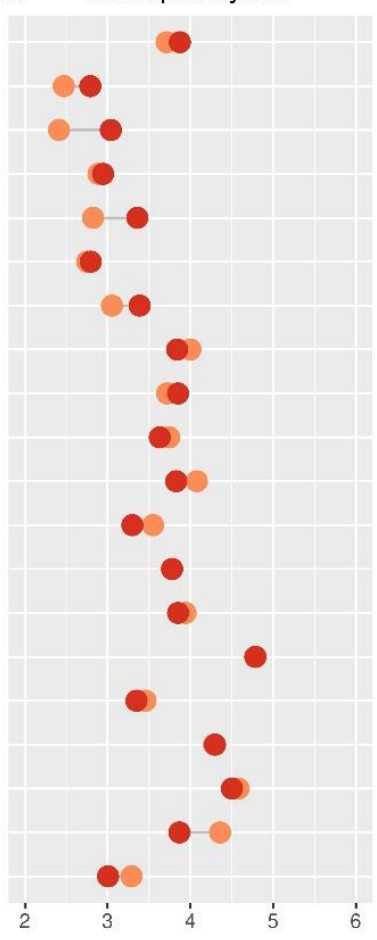

Susceptibility: others

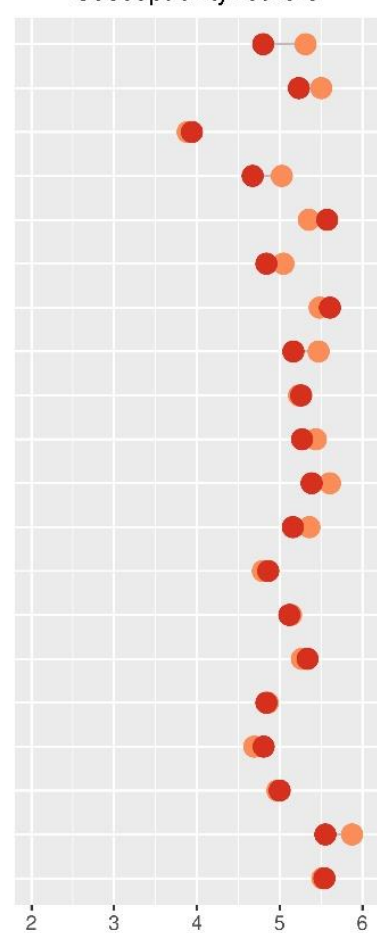

Figure S1. Changes to perceived susceptibility to biased decomposed to perceived selfsusceptibility and others-susceptibility: Experiment 1

Notes: Dots correspond to means computed across participants. Biases are presented based on size of reduction in blind spot in $\mathrm{L} 2$, in descending order. 


\section{Experimental instructions}

(in English (L2))

On the following pages you will see [21 in Experiment 1/7 in Experiment 2] tendencies that people show in their psychological behavior. Your task will be to rate how much you show such a tendency, and how much an average Pole shows such a tendency (in your opinion). Please rate the tendency to show such behavior on a scale of 1 to 7 , where $1=$ not at all, $7=$ very much.

\section{[Descriptions of biases, shown in Table S1; the biases were presented in a random order]}

How well did you understand the descriptions of human tendencies? Please rate on a scale of 1 to 10 , where $1=$ not at all, $10=$ completely .

Which of the following tendencies was not mentioned during the survey?

[Correct answer: Ikea effect]

What is your gender? [Male/Female/Other/Prefer not to say]

What is your highest level of education? [Primary education/Secondary education/Bachelor (or equivalent)/Masters (or equivalent)/Doctoral (or equivalent)]

What is your age (in years)?

At what age did you start learning English (in years)?

How would you rate your language skills in Polish and English? Please rate on a scale of 1 (very poor) to 7 (very good). [Separate writings for speaking/listening/reading/writing; participants were asked this question in Experiment 2]

How would you rate your knowledge of the English language? Please rate on a scale of 1 to 10 , where $1=$ very poor, $10=$ excellent .

Did you participate in a secondary-school English language exam (matura), and if so, at what level (select the higher-tier if you took both)?

What was your score in the secondary-school English language exam (matura), in the highest tier you took, in \%? [only shown for participants that had this exam]

If you have any comments, please put them in the box below: 